\title{
CJLT

\section{Student Perceptions of Using Tablet Technology in Post-Secondary Classes Perceptions des étudiants quant à l'utilisation des tablettes électroniques dans les classes universitaires}

Colin F. Mang, Nipissing University

Leslie J. Wardley, Nipissing University

\begin{abstract}
This paper assesses students' attitudes towards using tablets, such as the Apple iPad, in university classes. Tablets are found to be a substitute for laptop computers. Students initially expressed a great deal of optimism regarding the technology, and, although their views diminished slightly as they gained experience with using a tablet, their attitude towards the technology remained overwhelmingly positive. Most students experienced an easy transition from using a laptop to using a tablet. Furthermore, once students adopted the tablets in place of their laptops for in-class use, the types of tasks they performed with the tablets differed from the types of tasks they had previously performed with the laptop. Overall, the tablets reduced the incidence of off-task behaviour during lectures such as using chat and social networking applications.
\end{abstract}

Keywords: higher education, iPad, post-secondary education, student perceptions, tablet, technology

\section{Résumé}

Cet article évalue les attitudes des étudiants quant à l'utilisation de tablettes électroniques telles que le iPad d'Apple dans les classes universitaires. Les tablettes sont considérées comme des substituts aux ordinateurs portables. Les étudiants ont d'abord exprimé beaucoup d'optimisme à l'égard de cette technologie, et bien que leur perception se soit légèrement dégradée avec l'expérience de la tablette, leur attitude envers la technologie est restée très positive. La plupart des étudiants ont effectué une transition facile entre l'utilisation d'un ordinateur portable et celle d'une tablette. En outre, une fois que les étudiants ont adopté en classe les tablettes à la place de leurs ordinateurs portables, les types de tâches qu'ils accomplissaient avec les tablettes ont différé des celles qu'ils effectuaient précédemment avec l'ordinateur portable. Dans l'ensemble, 
les tablettes ont réduit les cas de comportements hors tâche durant les cours, comme l'utilisation du tchat et des réseaux sociaux.

Mots-clés: enseignement supérieur, iPad, éducation postsecondaire, perceptions des étudiants, tablettes électroniques, technologie

\section{Introduction}

Since the release of the iPad by Apple in 2010, tablets have become a popular consumer electronic device. This technology allows users to easily access the Internet, view multimedia content, take pictures, and write notes and emails from any location. Although many of these features are already available with the use of laptop computers or smartphones, tablets are superior to those devices as tablets are smaller and lighter than laptops but offer larger screens than smartphones. However, while the advantages and disadvantages of using laptop computers in higher education has been well documented over the past decade, tablets offer a distinct alternative for in-class use, which has only recently be explored.

Laptop and tablet technologies have many similarities. Each technology can provide Internet connectivity, which allows students to perform research in class, as well as access email and communicate using social networking applications. Both technologies allow students to type lecture notes electronically or access electronic lecture notes that have been provided by their instructor. As well, tablets and laptops allow students to utilize electronic versions of textbooks, which reduces the cost of the books and the effort required to carry them, and both allow the students to access multimedia content, whether for course related purposes or for personal use. Tablets do represent a powerful new computing tool for classroom use; however, they may not be perfect substitutes for laptop computers.

Tablets possess some disadvantages relative to laptops, which must be considered carefully before adopting tablets for in-class use. Although many software applications have been created for tablet, the variety and functionality of the applications often lags behind applications written for personal computers. The document generating capability of a tablet is less advanced than that of a laptop; word-processing, spreadsheet, and presentation software applications for traditional computers offer a wider variety of features than the software applications available on tablets. The "on-screen" virtual keyboard creates a difficult surface for keyboarding; however, physical keyboard attachments are now available for many tablets. Finally, tablets make use of an operating system and user interface that are quite different from that found on a standard desktop or laptop computer in the way that software applications are used and files are stored; conversion to using the technology thus requires additional learning on the part of the user.

Despite the tablet's limitations, with the right management of expectations, with proper strategic planning, and with appropriate support systems, there are many reasons why this new technology can advance learning. Tablets provide many unique advantages over laptop computers; for example, tables are smaller and more easily transported. As well, they typically have longer battery life. Most importantly, tablets allow the user to capture handwritten text and drawings, which is a key benefit for students taking notes in classes where mathematics formulas, equations, and graphs are prevalent. 
As competition for students has intensified among North American universities, the use of tablets may be used as a "gimmick," a means of differentiating the educational experience from that of other institutions. However, whether or not tablets actually improve student engagement with the course material and whether students themselves actually "like" using the new technology is of considerable importance if institutions are to promote the use of tablets as a competitive educational advantage.

\section{Purpose of the study}

Therefore, this paper assesses student views towards the use of tablets in higher education based on an experiment conducted in 2011. The purpose of the study is to: 1) examine students' preferences for using technology for educational purposes; 2) identify their perceptions of how the tablet technology did or did not improve their learning; 3) explore students' overall level of satisfaction with using the technology in class, to determine whether students hold positive or negative views of the tablet technology; 4) examine differences between the ways students use the tablet and the way they use laptop computers in class to determine the level of substitutability between the technologies; and 5) explore the off-task use of technology during lectures.

\section{Literature Review}

\section{Use of technology for educational purposes}

A growing number of studies have evaluated the integration of wireless computing technologies in the classroom. Barak, Lipson, and Lerman (2006) explored the integration of laptop computers in engineering classes at the Massachusetts Institute of Technology and found that the technology enhanced interaction among the students and between the students and the instructor. They also found that the students held largely positive attitudes about using the technology in class. Cismaru and Cismaru (2011) surveyed the use of laptop computers in Canadian universities finding that wireless access across campuses is now nearly universal, and 30 institutions have one or more programs that require the use of a laptop. Kay and Lauricella (2011a, 2011b) discussed the benefits of using laptops in higher education, which included improvements in note-taking, organization, and collaboration skills among students. Percival and Percival (2009) examined the implementation of a mandatory laptop-use program across an entire university campus and found that strategies for effective integration differed markedly by academic discipline. Most importantly, Gabriel, Campbell, Wiebe, MacDonald, and McAuley (2012) showed that first year university students now have certain "expectations" surrounding the use of technology in the classroom, and many have a preference for lecture content being communicated electronically.

More recently, the growing popularity of tablets, which began in 2010, has introduced a competing technology, which has the potential to displace laptop usage in higher education classrooms. Goral (2011) described the primary advantages of using tablet technology which included using software to enhance critical thinking and creativity, using electronic texts and readings which offered cost savings for students, and enhancing interaction among students and faculty. Mang and Wardley (2012) provided suggestions for ways which faculty could integrate the use of tablets into their classrooms, including using the device for taking lecture notes, for reading articles, for conducting research during debates, and for sharing work done in class, in 
order to keep students actively engaged with the device. Tanaka, Hawrylyshyn, and Macario (2012) also demonstrated the feasibility of using iPads to instruct anesthesiology students. However, as tablets are a technology that has only recently been introduced; Gawelek, Spataro, and Komarny (2011) have noted the still limited amount of peer-reviewed literature exploring the use of that technology for academic purposes.

\section{Off-task use of technology in classrooms}

While authors such as Kim, Mims, and Holmes (2006) have noted benefits from the introduction of wireless technology in higher education, such technologies can also create significant hindrances to learning. Barkhuus (2005), Fried (2008), Hembrooke and Gay (2003), and Kay and Lauricella (2011a, 2011b) all found that laptops posed a significant distraction for students, as the students could use them for off-task activities such as instant messaging, gaming, and watching movies instead of focusing on the lecture. Aguilar-Roca, Williams, and O'Dowd (2012) actually showed that laptop users had significantly lower test scores in a biology course when compared to students who did not use laptops during lectures. Junco (2012), Junco and Cotten (2012), and Wood et al. (2012) explored the extent to which students use communication technologies, including both laptops and also cell phones, for "multi-tasking" during lectures, i.e. diverting attention from class activities to off-task activities. These studies found that some offtask activities, such as using Facebook and MSN chat on laptops, and text messaging on cell phones, diminished academic performance. Other researchers such as Maxwell (2007) have advocated banning communication devices from lecture halls in order to help students focus more attentively during lectures.

\section{Student perception of in-class use of technology}

Despite the academic drawbacks to using technology in class, students often still have a positive perception, or at least a preference towards, using these technologies during lectures. Lauricella and Kay (2010) reported that students perceived the laptops to be helpful for many academic tasks including note-taking and organization which assisted their academic progress. Vuojärvi, Isomäki, and Hynes (2010) explored how students in laptop-mandated programs integrated the laptop into their personal and academic lives, finding that students who had a higher proficiency with information technology, and especially those who had prior experience with the software used in their classes more easily adopted the laptop as a learning tool.

Laptops are a mature technology, and their operation is nearly identical to that of another technology, desktop computers, so students are likely to have had significant experience with at least one of these technologies prior to entering post-secondary education. However, as tablets are a relatively new technology, and the operating system and software is unfamiliar to some students, the students may not benefit from any experience advantage when attempting to use tablets for academic purposes. Fischman and Keller (2011) and Wieder (2011) noted that, during trials of tablets at Stanford and at the University of Notre Dame, many students found adapting to the device difficult and, within a few weeks, switched back to using their laptops. In those instances students expressed frustration with the user-interface, which required both typing on a virtual "keyboard" projected on the lower portion of the screen coupled with drawing with one's fingertip. However, since that time, physical keyboards and handwriting styluses have now become available for many types of tablets to remedy these issues. 
Nevertheless, Eichenlaub, Gabel, Jakubek, McCarthy, and Wang (2011) reported that students at Ryerson University felt they benefited academically from using tablets, Weider (2011) reported that tablets improved collaboration among students at Pepperdine University and improved students' participation in class discussions at Reed College, and BizEd Magazine ("Schools Release iPad Studies", 2011) found that $75 \%$ of students at Oklahoma State University who participated in a trial of tablets in their classes believed the tablets improved their learning - 97\% of students in that trial indicated they would prefer to continue using tablets in their classes.

\section{Comparison of tablet and laptop}

Most important for the purpose of this study, Kinash, Brand, and Mathew (2012) and Rossing, Miller, Cecil, and Stamper (2012) each present results from surveys measuring student perceptions of tablets, where students were given Apple iPads to use during one or more class sessions of a course and then asked about their feelings towards the device. Rossing et al. found that students generally had a very positive perception of the iPad in terms of both learning and motivation to learn the course content; however, Kinash et al. found that while students believed the iPads increased motivation, they did not believe the devices significantly improved their learning. Rossing et al. also report that students believed that the iPad aided in group collaboration, that the iPad increased the amount of attention they devoted to the class material, and that the iPad was more convenient than a laptop computer. However, students in Rossing et al.'s study were only exposed to the iPads between one and seven times over the course of their semester, and did not keep the iPads to experiment with on their own, but rather returned them at the end of each class session. As well, the students were given the iPads to use for specific activities, rather than encouraged to utilize the iPads for general classroom use. In contrast, students in Kinash et al.'s study were encouraged to make use of the tablets in any way they wished. Kinash et al. recorded off-task uses of the device and found that the most common activities were web-surfing, using Facebook, and checking email, and that these activities were more prevalent than accessing the university's learning management system. Nevertheless, both Kinash et al. and Rossing et al. provide only post-experience perceptions of the technology and do not approach the subject of how student perceptions of the device might change over repeated uses, or how student activities regarding off-task behaviours are influenced by the tablets, a gap which this paper will explore.

\section{Methodology}

\section{The use of tablets in class}

To test the students' reactions to using tablets in a university class, we conducted a trial of the technology in the summer semester of 2011. We selected three classes being offered over the six week summer term: a first-year introductory organizational studies class, a second-year ethics class, and a second-year economics class, and we provided an iPad to each student to keep for the duration of the term. We chose to use iPads for three reasons: first, we were both already familiar with using the iOS operating system from using iPods and iPhones; second, anecdotal evidence suggested that many of the students were already familiar with the iOS operating system which, given Vuojärvi et al.'s (2010) assertion regarding previous software experience, should have lead to greater acceptance of the technology; third, the iPad was the market leader at 
the time with approximately 68\% market share (Forbes, 2011); and finally, it was also being pilot-tested at other universities across North America.

\section{The classroom environments}

The three courses selected provided the opportunity to test the uses of the tablets across a range of classroom environments. The introductory organizational studies class combined a didactic lecture style with interactive discussions and research. The use of the iPad created an expansion to the class resources that had not previously been available. First, the instructor presented lecture content visually and verbally; visual content was primarily comprised of slideshow presentations that allowed students to download copies of the slideshows to their iPads (in a PDF format) in advance of the classroom lecture. Then during the lecture these slides created an excellent resource, as the instructor was able to highlight important concepts and make notations on the slides as the lecture progressed and share them with the class through Blackboard (the university's learning management system). This method was different from previous semesters where students had needed to either print the lecture slides ahead of time or view them on laptop computers and the instructor was restricted from easily adding collaborative notations to the slides in real-time as the lecture progressed and then sharing the updated notes with the class electronically. Secondly, students were able to make notes using the iPad and an annotation application. Some of the notes were based on group breakout exercises and could be displayed using an overhead projector for class review and discussion. Although the previous use of a white board and markers had created the same ability to share group work and individual thoughts with the whole class, the use of the iPad allowed the class to share the displayed content with the other class members through electronic files - replacing the tedious and time consuming effort of copying the information using individual handwritten notes. Finally, to foster research in this first-year class where students may not be familiar with using the library resources for research purposes, for each class students were required to post, in the university's learning management system, an academic article with notations added that related to a particular concept explored in the assigned textbook readings. These research articles and notations became the basis of classroom discussion and allowed students a catchment of annotated sources when preparing their individual research papers. By breaking the work on the assigned paper into smaller steps and performing the analysis in-class, where students could add additional notes to the downloaded annotated files, the instructor was able to provide guidance and support throughout the research process.

The ethics class primarily involved classroom discussions of ethical concepts and practices, and analysis of various examples. There was a "lecture" component where the instructor explained the underlying theoretical frameworks and textbook concepts; however, the focus was on instructor lead in-class discussions and debates. Again, the use of the iPad facilitated making notations to the overhead slides as the lecture progressed. In addition, interspersed within the lecture were debates surrounding the concepts presented. The introduction of, and universal access to, the iPads provided an alternative method for information gathering during these periods of the class. In previous semesters, students would refer to their textbook readings or to prior research during the debates; thus, students would often need to rely on generalizations because they lacked the ability to instantly research pertinent facts to support their claims during class debates. The introduction of the iPad here provided an avenue for students to conduct "onthe-spot" research to find supporting, or contradictory, evidence during class debates. 
Furthermore, the iPads also provided an alternative means of participating in classroom discussions. In previous semesters, all discussions were oral, leaving students who were shy or intimidated about speaking about sensitive topics in front of the whole class at a disadvantage when attempting to gain class participation marks. However, because of the Internet connectivity provided universally by the iPad, instead of simple oral discussions, the instructor gave students the option to post initial or on-demand comments on a discussion board contained within the university's learning management system, which could then be orally discussed in class. The instructor had the ability to view the comments posted and their authors and assign participation marks based on these efforts, but the written record of the student comments could be kept anonymous when viewed by the class. These postings helped to frame the class discussions as students could refer back to them in class. The ability to post comments electronically proved an added benefit over previous classes where comments could be lost as no one recorded them as they were spoken. As well, the fact that a record of their contributions remained available led students to put greater thought and effort into their comments.

The economics class provided yet another learning environment to test the tablets. Like the organizational studies class, the economics class included a large lecture component where the instructor presented the course material using a slideshow. The slides were made available to students prior to the lesson in a printable format; however, again, the iPad provided an alternative platform for viewing the lecture notes. Unlike the organizational studies course, the economics course contained a large quantitative component and students were repeatedly required to graph and solve equations. In previous semesters, such work would be done with pen(cil) and paper, and with a calculator; however, ability to handwrite directly onto the iPad, and also the ability to perform calculations using a calculator application, provided alternatives for the students. In addition, the course contained discussion of current events in business and politics. Whereas discussions in previous semesters relied largely on the students' prior reading of selected issues, the introduction of the iPad allowed students to suggest new topics in class if they found a particular news item, which they felt would be of interest.

While the core content of the three classes remained unchanged, the iPads facilitated a different and at times deeper degree of interaction among the students and between the students and the instructor. The iPads provided alternatives to traditional classroom activities such as reading and annotating pre-prepared lecture notes; however, they also provided new opportunities for students to gather information and enhance their participation in classroom discussions.

\section{Participant profile}

We chose the summer semester for the experiment because course enrollments in the summer are typically smaller than in the fall and winter terms which reduced the number of tablets we would need to provide, thus helping to control the cost of the experiment; the smaller class enrolments also ensured that we would be able to provide individual attention and support to each student as they adapted to the technology. In large classes, providing individual support would have been unfeasible. As well, because of the limited number of summer course offerings on our campus, students who might have been apprehensive about using the iPad did not have many alternatives. For two of the classes, we advertised ahead of registration that iPads would be used in class. However, being concerned that the introduction of new and unfamiliar technology might discourage some students from registering, we did not advertise the use of iPads for the third 
class, which actually contained the greatest number of students at 21 , but instead surprised them on the first day.

The total enrollment for the three classes was 49 students; however, two students were enrolled in multiple classes, so the total number of participants was only 47. During the first lecture of each course, we asked the students to participate in a survey covering their previous technology use and their expectations or apprehensions regarding the tablet. 42 of the students participated in the survey. Following the conclusion of the courses, 18 of the students participated in a follow-up survey to discern whether their experiences matched their expectations, and whether they believed they had benefited from using the tablet in class. The lower level of participation in the second survey somewhat limited our findings but the responses still allowed us to determine if differences were present in the pre and post student reactions. While it would have been favourable to collect actual usage data directly from the devices, privacy concerns limited our ability to do so and therefore all results were self-reported by the students, which is a limitation of this study.

Table 1 provides demographic information about the students participating in the tablet trial who completed the pre-course and post-course surveys. At the beginning of the course, $62 \%$ of the students indicated that they were very comfortable and another $31 \%$ indicated that they were comfortable with using personal computers and software applications prior to enrolling in the course; only two of the students indicated that they were not comfortable, so we could be sure that the majority of students would be open to using technology.

Table 1: Demographic information about the students participating in the iPad trial

\begin{tabular}{|l|c|c|}
\hline \multicolumn{2}{|c|}{ Pre-course } & Post-Course \\
\hline Gender & 18 & 8 \\
\hline Male & 24 & 15 \\
\hline Female & \multicolumn{2}{|c|}{} \\
\hline \multicolumn{3}{|l|}{} \\
\hline Age & 25.05 & 23.13 \\
\hline Average & 3 & 2 \\
\hline Under 20 & 14 & 8 \\
\hline $20-22$ & 10 & 8 \\
\hline $23-29$ & 7 & 2 \\
\hline $30-39$ & 2 & 1 \\
\hline $40+$ & 4 & 1 \\
\hline No age reported & \multicolumn{2}{|c|}{} \\
\hline \multicolumn{2}{|c|}{ Number of Years of Post-Secondary Education Completed } \\
\hline 1 & 4 & 3 \\
\hline 2 & 4 & 1 \\
\hline 3 & 14 & 6 \\
\hline 4 & 7 & 5 \\
\hline 5 & 7 & 6 \\
\hline Not reported & 5 & 1 \\
\hline
\end{tabular}




\section{Results}

\section{Students' preferences for using technology}

Both at the beginning and at the end of the course, the students were asked a variety of questions regarding their preferences for technology use in education. Questions were answered on a fourpoint Likert scale, with $1=$ Strongly Disagree, $2=$ Disagree, $3=$ Agree, and $4=$ Strongly Agree. Results are reported in Table 2 with the questions given at the beginning of the semester listed and alternative wording used at the conclusion of the semester appearing in brackets. Table 2 also provides the results from one-tailed t-tests for the difference between the average results from each survey.

Table 2: Average responses for preferences of technology use in education

\begin{tabular}{|lccc|}
\hline & $\begin{array}{c}\text { Pre-Course } \\
\mathbf{n = 4 2}\end{array}$ & $\begin{array}{c}\text { Post-Course } \\
\boldsymbol{n}=\mathbf{1 8}\end{array}$ & $\begin{array}{c}\text { t-test } \\
\text { (one-tail) }\end{array}$ \\
\hline $\begin{array}{l}\text { I prefer to use technology to enhance my } \\
\text { learning. }\end{array}$ & 3.51 & 3.50 & 0.07 \\
\hline $\begin{array}{l}\text { I have a negative perception about the use } \\
\text { of mobile technology in this course. }\end{array}$ & 1.53 & 1.69 & 0.71 \\
\hline $\begin{array}{l}\text { I find (found) instruction on using the iPad } \\
\text { easy to follow. }\end{array}$ & 3.33 & 3.25 & 0.51 \\
\hline $\begin{array}{l}\text { I feel I will (can) access technical support } \\
\text { for the iPad when needed. }\end{array}$ & 2.98 & 3.00 & 0.14 \\
\hline$* p<0.10 * * p<0.05 * * * p<0.01$ & & & \\
\hline
\end{tabular}

At the beginning of the course, nearly all students indicated that they had a strong preference for using technology to enhance their learning, a view that remained consistent to the end of the course. As well, at the beginning of the course, students generally indicated that they did not have a negative perception of the use of mobile technology, and although their responses did, on average, become slightly more negative by the end of the course, the difference was not statistically significant. These results were consistent with $93 \%$ of the students indicating that they were comfortable with computers and software applications. Most students found the operation of the iPad easy to grasp, and many of the students indicated that they would access technical support when needed. Again, their views on these matters did not change over the course of the semester. Overall, we concluded that the students were generally technophiles; thus, very receptive to new forms of technology.

\section{Students' perceptions of in-class use of tablets}

Next, we asked students about their individual learning styles and about their perceptions of the iPad's role in their learning. Again, questions were answered on a four-point Likert Scale and the results are reported in Table 3. Again, questions asked at the beginning of the course are included in the table with alternative wording used at the end of the course in brackets.

At the beginning of the semester, the students exhibited a great deal of excitement regarding the use of the device. Most students strongly agreed that the iPad would assist them with research 
and would help them to participate more actively in class discussion. As well, most believed that the iPad was a suitable tool for educational purposes. By the end of the semester though, their views had changed somewhat. As shown in Table 3, average responses to all questions declined. While the decline was statistically insignificant in most cases, the lack of significance may have been a function of the small sample size used. The decline was statistically significant at the 10\% level for two key questions relating to students' perception of the design and infrastructure. When observing the survey results at the end of the semester, we see that the students still maintained overall positive views of the iPad. Most students continued to agree or strongly agree with the statements that the iPad was good for their learning and assisted them in research and class discussions. The strongest responses were observed for the questions related to possessing necessary technology skills for, and overall enjoyment resulting from, using the iPad. We concluded that the students were likely enamored with the device on the first day; because none of them owned a tablet previously, their lack of experience with the technology led to overly high expectations of the value of the device. After experiencing the device for six weeks, the students had a more realistic comprehension of the value of the device in an educational context resulting in their final perceptions being reported as lower than their initial expectations. Nevertheless, even after experiencing the device for six weeks, their views of the use of the device in an educational context remained largely positive, which is consistent with Rossing et al.'s (2012) findings. Most students indicated that they would be interested in taking another course that used iPads.

Table 3: Average responses for perceptions about the iPad in education

\begin{tabular}{|c|c|c|c|}
\hline & $\begin{array}{c}\text { Pre-Course } \\
\quad n=42 \\
\end{array}$ & $\begin{array}{c}\text { Post-Course } \\
n=18 \\
\end{array}$ & $\begin{array}{c}\text { t-test } \\
\text { (one tail) }\end{array}$ \\
\hline $\begin{array}{l}\text { The iPad assists me to search for more facts } \\
\text { than traditional learning methods. }\end{array}$ & 3.27 & 3.04 & 0.31 \\
\hline $\begin{array}{l}\text { I believe the iPad will assist (assisted) me } \\
\text { to participate more actively in discussions } \\
\text { than traditional learning methods. }\end{array}$ & 3.17 & 3.16 & 0.03 \\
\hline $\begin{array}{l}\text { I perceive the design of the iPad to be good } \\
\text { for self-directed learning. }\end{array}$ & 3.43 & 3.13 & $1.83 *$ \\
\hline $\begin{array}{l}\text { Overall, I believe that I have adequate } \\
\text { technology skills to use the iPad to enhance } \\
\text { my learning. }\end{array}$ & 3.59 & 3.52 & 0.44 \\
\hline $\begin{array}{l}\text { Overall, the iPad infrastructure is efficient } \\
\text { for learning. }\end{array}$ & 3.38 & 3.13 & $1.69 *$ \\
\hline I will enjoy (enjoy) using the iPad. & 3.55 & 3.42 & 0.62 \\
\hline $\begin{array}{l}\text { If given the opportunity, I would choose to } \\
\text { enroll in another course that used iPads. }\end{array}$ & $--^{\dagger}$ & 3.36 & -- \\
\hline
\end{tabular}

\section{Comparison of tablet to laptop}

Our third series of questions focused specifically on how the students used the device in class and how they compared the use of the tablet with the use of a laptop computer. We asked the 
students whether, prior to enrolling in the iPad trial course, they regularly brought a laptop to their classes. We also asked them whether, during the course of the iPad trial, they continued to bring a laptop in addition to the iPad to class. Furthermore, we asked them how they used the devices during the lectures. The results are presented in Table 4 where (B) indicates that the question was asked at the beginning of the semester and (E) indicates that the question was asked at the end of the semester. The results of chi-squared tests for the corresponding contingency tables to ascertain whether behaviours changed as a result of the introduction of the iPads are also reported.

Table 4: Student use of technology devices during lectures

\begin{tabular}{|lccccc|}
\hline & Never & Sometimes & Regularly & Always & $\chi^{2}(d f=3)$ \\
\hline $\begin{array}{l}\text { (B) Prior to this course I have } \\
\text { regularly brought a laptop to } \\
\text { class. }\end{array}$ & $7.1 \%$ & $16.7 \%$ & $9.5 \%$ & $66.7 \%$ & $17.22^{* * *}$ \\
(E) In addition to using the iPad & $17.4 \%$ & $47.8 \%$ & $21.7 \%$ & $13.0 \%$ & \\
$\begin{array}{l}\text { I regularly brought a laptop to } \\
\text { class. }\end{array}$ & & & & & \\
\hline $\begin{array}{l}\text { (B) When I bring a laptop to } \\
\text { class I used it for taking notes } \\
\text { and other course related } \\
\text { purposes. } \\
\text { (E) During class I used the iPad }\end{array}$ & $2.4 \%$ & $7.1 \%$ & $40.4 \%$ & $50.0 \%$ & 4.29 \\
for taking notes and other course \\
related purposes.
\end{tabular}

Although the majority of students had been in the habit of bringing laptop computers to their classes on a regular basis, the introduction of the iPad significantly diminished this behaviour. Very few students reported that they continued to regularly bring or always brought laptops to class now that they had the iPad. Most students indicated that, prior to enrolling in the iPad course, they had used laptops in class for taking notes or for other course related purposes. Once the students were given iPads, most indicated that they used the iPad for these purposes. However, there existed a minority of students, $13 \%$ of the total, who indicated that they did not 
adopt the iPad for course related use. Although we encouraged the students to use the iPad for their course, we did not force them to do so, and they still had the option of using a laptop computer to complete any tasks assigned which required Internet communications. Ultimately, although most students readily adopted the iPad, some chose not to do so. As well, nearly half the students indicated that the fact that they would need to return the iPad at the end of the semester negatively affected their investment in using the device. If the students were given the iPads to keep, they may have made a greater effort to integrate use of the device into their learning routine.

\section{Off-task use of technology during lectures}

When we asked the students about their non-course related usage during the lectures, we obtained a surprising result. Although the switch from using laptops to using iPads did not reduce the general reported usage of a device for non-course related purposes during the lecture, the switch to the iPad did substantially reduce the usage of some popular software applications that previously had been major distractions for the students. As shown in Table 5, statistically significant declines in non-course related use were observed for personal email, Facebook use, and chat client usage as indicated by the z-tests for the difference between two proportions. In fact, the level of chat client usage dropped to zero with the introduction of the iPad. We attribute the decline to the fact that iPads cannot display multiple application windows simultaneously. Unlike a laptop computer which would allow a student to keep a word processor window open for taking lecture notes while also having a chat window open to converse with friends and a web browser open to surf the internet, the iPad's software only allows one application to be visible at a time. Chat functionality becomes impractical because the user would either be forced to keep the chat window open continuously to monitor the conversation and thus lose all other functionality with the device, or the user would have to frequently transfer back-and-forth between the chat application and other applications in order to monitor the conversation, which would be cumbersome. Similarly, the need to take notes as the lecture progressed also made using other web-based applications difficult. Overall, the fact that the iPad significantly reduced non-course related application usage during lectures represented a significant advantage for the device when compared to laptop computers.

Table 5: Non-course related usage by students during a lecture

\begin{tabular}{|l|l|l|l|l|}
\hline $\begin{array}{l}\text { \% Of Previous Laptop Users who } \\
\text { used the Laptop during lecture for ... } \\
\text { (Prior to iPad Course) }\end{array}=31$ & $\begin{array}{l}\text { \% Who Used the iPad during } \\
\text { lecture for... } \\
n=18\end{array}$ & $\begin{array}{l}\text { z-test } \\
\text { (one tail) }\end{array}$ \\
\hline Personal Email & $80.6 \%$ & Personal Email & $61.1 \%$ & $1.49^{*}$ \\
\hline Facebook & $83.9 \%$ & Facebook & $66.7 \%$ & $1.39^{*}$ \\
\hline $\begin{array}{l}\text { MSN / Facebook Messenger } \\
\text { / Other chat }\end{array}$ & $35.5 \%$ & $\begin{array}{l}\text { MSN / Facebook } \\
\text { Messenger / Other chat }\end{array}$ & $0 \%$ & $2.87 * *$ \\
\hline YouTube & $41.9 \%$ & YouTube & $33.3 \%$ & 0.60 \\
\hline Twitter & $3.2 \%$ & Twitter & $5.5 \%$ & -0.39 \\
\hline Other & $6.4 \%$ & Other & $5.5 \%$ & 0.13 \\
\hline
\end{tabular}

*Significant at the $10 \%$ Level ***Significant at the $1 \%$ Level 


\section{Conclusion}

Based on a trial of iPad use in three university courses in the summer semester of 2011, we have shown that students generally hold positive views of the device's use as a learning tool in their education. The students initially exhibited a high level expectation for the usefulness of the device; although their overall assessment of the device at the end of a six week trial period was somewhat lower than their original expectations, their assessments were still largely positive and most students indicated that they would choose to enroll in another course using the devices if given the opportunity.

Although the majority of students previously brought laptop computers to their university classes, after the introduction of the iPads, very few of them continued to do so. Most students converted easily to the new technology and the iPad replaced their laptops for note-taking and other course-related uses. The switch to the iPad also significantly reduced students' non-course related software application usage during lecture times. The iPad's operating system interface made the use of chat clients impractical and the use other off-task web-based uses difficult.

One major issue in our study was the fact that students were not able to keep the iPads beyond the six week trial, a fact which many students felt reduced the time they spent learning about the device's functionality which may have restricted a fuller integration of the device into their learning routines. Another issue was the small number of students participating in our study; while the small number of students helped to keep the costs of the pilot study low, a larger and broader sample would have been preferable. Nevertheless, our sample did contain students with a range of ages and years of post-secondary experience. Although the results from this sample of iPad users shows positive potential for tablet usage in higher education, more research is necessary, especially among those students who own tablets, to determine the level to which they have integrated the device into both their academic and personal lives. Nevertheless, the results of this survey should provide positive support to faculty at different institutions who are considering experimenting with tablet use, or adopting mandatory tablet use, in their classes. Not only do the tablets provide educational advantages relative to laptops, including easier notetaking ability and a lower rate of "distracting" non-course related use, but the students also have a positive perception of the technology and a majority of them chose to switch away from their laptops and towards the iPads for course related uses.

\section{References}

Aguilar-Roca, N. M., Williams, A. E., \& O'Dowd, D. K. (2012). The impact of laptop-free zones on student performance and attitudes in large lectures. Computers \& Education, 59(4), $1300-1308$.

Apple Can Run to \$510 with iPad Market Share Momentum. (2011, September 21). Forbes, Retrieved from http://www.forbes.com/sites/greatspeculations/2011/09/21/apple-can-runto-510-with-ipad-market-share-momentum 
Barak, M., Lipson, A., \& Lerman, S. (2006). Wireless Laptops as Means for Promoting Active Learning in Lecture Halls. Journal of Research on Technology in Education, 38 (3), $245-$ 263.

Barkhuus, L. (2005). Bring your own laptop unless you want to follow the lecture: Alternative communication in the classroom. Proceedings of the 2005 international ACM SIGGROUP conference on Supporting Group Work, 140-143.

Cismaru, R. \& Cismaru, M. (2011). Laptop use during class: A review of Canadian universities. Journal of College Teaching \& Learning, 10(11), 21-28.

Eichenlaub, N., Gabel, L., Jakubek, D., McCarthy, G., \& Wang, W. (2011, September). Project iPad: Investigating tablet integration in learning and libraries at Ryerson University. Computers In Libraries, 17-21.

Fried, C. B. (2008). In-class laptop use and its eVects on student learning. Computers \& Education, 50, 906-914.

Fischman, J., \& Keller, J. (2011). College Tech Goes Mobile. Chronicle of Higher Education, $58(1), 50$.

Gabriel, M. A., Campbell, B., Wiebe, S., MacDonald, R. J., \& McAuley, A. (2012). The role of digital technologies in learning: Expectations of first year university students. Canadian Journal of Learning and Technology, 38(1).

Gawelek, M. A., Spataro, M., \& Komarny, P. (2011). Mobile perspectives: On iPads why mobile?, EDUCAUSE Review, 46(2), 28-32.

Goral, T. (2011, January). Take II Tablets. University Business, 46-49.

Hembrooke, H. \& Gay, G. (2003). The laptop and the lecture: The effects of multitasking in learning environments. Journal of Computing in Higher Education, 15 (1), 46-64.

Junco, R. (2012). In-class multitasking and academic performance. Computers in Human Behavior, 28(6), 2236-2243.

Junco, R. \& Cotten, S.R. (2012). No A 4 U: The relationship between multitasking and academic performance. Computers \& Education, 59(2), 505-514.

Kay, R. H. \& Lauricella, S. (2011a). Exploring the benefits and challenges of using laptop computers in higher education classrooms: A formative analysis. Canadian Journal of Learning and Technology, 37(1), 1-18.

Kay, R. H. \& Lauricella, S. (2011b). Unstructured vs. structured use of laptops in higher education. Journal of Information Technology Education, 10, IIP33 - IIP42.

Kim, S. H., Mims, C., \& Holmes, K. P. (2006). An introduction to current trends and benefits of mobile wireless technology use in higher education. AACE Journal, 14(1), 77-100. 
Kinash, S., Brand, J., \& Mathew, T. (2012). Challenging mobile learning discourse through research: Student perceptions of Blackboard Mobile Learn and iPads. Australasian Journal of Educational Technology, 28(4), 639-655.

Lauricella, S., \& Kay, R. (2010). Assessing laptop use in higher education classrooms: The Laptop Effectiveness Scale (LES). Australasian Journal of Educational Technology, 26(2), 151-163.

Mang, C. F., \& Wardley, L. J. (2012). Effective adoption of tablets in post-secondary education: Recommendations based on a trial of iPads in university classes. Journal of Information Technology Education: Innovations in Practice, 11, 301-317.

Maxwell, N. G. (2007). From Facebook to Folsom Prison Blues: How banning laptops in the classroom made me a better law school teacher. Richmond Journal of Law \& Technology, 14(2), 1-43.

Percival, J. \& Percival, N. (2009). A case of a laptop learning campus: How do technology choices affect perceptions?. ALT-J: Research in Learning Technology, 17(3), 173-186.

Rossing, J. P., Miller, W. M., Cecil, A. K., \& Stamper, S. E. (2012). iLearning: The future of higher education? Student perceptions on learning with mobile tablets. Journal of the Scholarship of Teaching and Learning, 12(2), 1-26.

Schools Release iPad Studies. (2011, July/August). BizEd Magazine, 60-63.

Tanaka, P. P., Hawrylyshyn, K. A., \& Macario, A. (2012). Use of tablet (iPad®) as a tool for teaching anesthesiology in an orthopedic rotation. Revista Brasileira de Anestesiologia, $62(2), 214-222$.

Vuojärvi, H., Isomäki, H., \& Hynes, D. (2010). Domestication of a laptop on a wireless university campus: A case study. Australasian Journal of Educational Technology, 26(2), 250-267.

Weider, B. (2011). iPads could hinder teaching, professors say. Chronicle of Higher Education, 57(28), A22-A23.

Wood, E., Zivcakova, L., Gentile, P., Archer, K., De Pasquale, D., \& Nosko, A. (2012). Examining the impact of off-task multi-tasking with technology on real-time classroom learning, Computers \& Education, 58(1), 365-374. 


\section{Authors}

Colin F. Mang is an economist and part-time instructor at Nipissing University's School of Business. His research focuses on consumer adoption and applications of new technologies as well as efficiency and administration in higher education. Email: colinm@nipissingu.ca.

Leslie J. Wardley holds a Lecturer faculty position in Nipissing University's School of Business. Her professional background includes university administration and small business management with a focus in project management. Her research has explored job design principals, diversity, organizational change, classroom technology and students' adaptation to university. Email: lesliew@nipissingu.ca. 